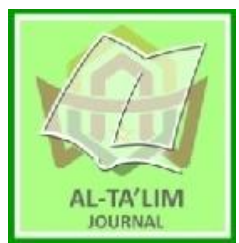

AL-TA'LIM JOURNAL, 27 (1), 2020, (1-15)

(Print ISSN 1410-7546 Online ISSN 2355-7893)

Available online at http://journal.tarbiyahiainib.ac.id/index.php/attalim

\title{
Contemplation-Based Learning: An Effective Learning Model for Serving Science and Self-Knowledge Integration
}

\author{
Received: $22^{\text {nd }}$ July 2019; Revised: 06 ${ }^{\text {th }}$ January 2020; Accepted: $27^{\text {th }}$ February 2020
}

Permalink/DOI: https://doi.org/10.15548/jt.v27i1.586

\section{Rina Delfita *)}

Institut Agama Islam Negeri Batusangkar, Indonesia.

E-mail: rinadelfita@iainbatusangkar.ac.id

\section{Ridwal Trisoni}

Institut Agama Islam Negeri Batusangkar, Indonesia.

E-mail:ridwaltrisoni@iainbatusangkar.ac.id

\section{Andrizal \\ Institut Agama Islam Negeri Bukittinggi, Indonesia. \\ E-mail: andrizaldel79@gmail.com}

\author{
Aidhya Irhas Putra \\ Institut Agama Islam Negeri Batusangkar, \\ Indonesia. \\ E-mail: aidhyaip@iainbatusangkar.ac.id
}

\section{Adripen}

Institut Agama Islam Negeri Batusangkar, Indonesia

E-mail: adripen@iainbatusangkar.ac.id

\begin{abstract}
The study aims to produce feasible a contemplation-based learning model based on the aspect of validity and practicality for Biology prospective teachers. Research and development (R\&D) using ADDIE model was used where the participants in this study were three Biology Education lecturers, three experts, and 35 students who enroll at first semester at Biology Education department in Batusangkar State Islamic Institute (IAIN) as experimental subjects. The instruments used is observation, interview and questionnaire. Means and standard deviations were calculated for finding the level of validity and practicality of the prototype. The results showed that contemplation-based biology learning model meet the characteristics of the learning model and characteristic of contemplation. The contemplative approaches used through deep reading essays and paid attention to figures related to the subject matter of General Biology courses. The values cultivated are values contained in the subject matter. The values that contained in the material are islamic values, it is alasma' ul husna. The contemplationbased learning model developed is feasible to be applied in the biology classroom with the most valid and very practical category. Thus, the contemplation-based learning model is a solution for overcoming the gap of serving science with selfknowledge and is an alternative learning model to integrate science and religion at Biology Education Department.
\end{abstract}

\section{*) Corresponding Author}

Keywords: Contemplation-based Biology learning model; integration of serving science and self-knowledge; integration science and religion.

How to Cite: Delfita, R., Trisoni, R., Andrizal, A., Putra, A., \& Adripen, A. (2020). Contemplation-based Learning: An Effective Learning Model for Serving Science and Self-knowledge Integration. Al-Ta lim Journal, 1(2). doi:https://doi.org/10.15548/jt.v27i1.586

\section{INTRODUCTION}

In the passing decade, universities have been subjected to serious critiques (Ergas, 2017), include universities in Indonesia, which is widely known from the "moral crisis". This also can be seen from the statement of Lewis (2006) that Havard University and other universities have been successful as creators and repositories of knowledge, but have forgotten the main role of education for university students. Universities have forgotten the fundamental role of undergraduate education is to help students grow up, to learn who they are, to search for a larger purpose for their lives and to leave university better human being. In other words, universities are only focused on 
creating knowledge or serving science. Barbezat \& Bush, (2014) also acknowledged that their higher education deviated and forgotten main role to create graduates who had good characters as well as creativity. The universities in Indonesia also forget it. It shows that knowledge is separated from the goal of education, to form a good person, having morality, good ethics, applying values and having a good relationship with each other. Simmer-Brown, (2009) interpreted that universities separated rationality with emotional and spirituality of student. Lelwica (2009) also stated that university only develops thinking skills. Thus, the existence of this separation gave birth to graduates who were academically clever but they were lack of moral aspects. So, it results "moral crisis".

In undergraduate program, Biology becomes the most common subject in Indonesia. Students claim that their courses teach that "everything is abaut biology" and ignores the values, norms, rules that exist in their religion and culture. Colby, Ehrlich, \& Sullivan, (2011)mentioned that in business undergraduated programs in USA, students claim that their course only teach about business and ignore religious values and norms of society. While in Islamic university in Indonesia are trying to integrate religious values in each subject matters, although it is only limited to foster religious theory, not to the level of practice in the form of learning models (Delfita and Andrizal, 2016). Some expert argued that these are symptoms of contemporary times in which economic thinking has been taking over education (Kandiko and Camille, 2010; Gilead, 2012), transforming Universities into marketplace players (Kleinman, Feinstein, \& Downey, 2013), and trying them with economic success in ways. These systemic and external contemporary conditions have something to do with this moral crisis. However, the bifurcation between "serving science" or "knowledge" and "self-knowledge" is not novelty of contemporary times. It was the heart of what may be a central aspect of this moral crisis (Ergas, 2017). Therefore, fostering the moral development of students through learning in each subject matter is very necessary psychologically, socially and globally. Self-knowledge is key to the cultivation of a life of meaning and virtue. An education that hopes to cultivate these qualities must in the curriculum there is serious attention to it. Self-knowledge can thus be considered to be a "curriculum" in its own right. It unfolds within a pedagogical space in which meaning becomes personal meaning within a social sphere and moral action becomes a deliberate choice (Ergas, 2017).

The practice of contemplation in learning is a very appropriate solution for fostering moral development. The practice of contemplation has been shown to increase ethical motivation and behave through various mechanisms. Walsh \& Shapiro (2006) stated that the practice of contemplation has been shown to increase sensitivity to the consequences of unethical actions such as guilt towards self and pain experienced by others, reduce motivation for wrongdoing such as anger and greed, and fostering moral. In students, it is known that the practice of contemplation enhanced ethics in making decisions (Ruedy \& Schweitzer, 2010) and developed morality (Shapiro et al., 2015). By promoting curiosity and fostering students' curiosity about experience during contemplation, they will train to focus and improve their self-control skills in an effort to explore the environment or become objects of contemplation in new and creative ways. Hart (2004) stated that when information is processed in depth, it is more reflective; then, information will be easily integrated with one another and will be maintained for a long time. Practicing contemplation and promoting learners' curiosity about their experiences during contemplation will help them to learn more effectively and reflectively. Barbezat and Pingree, (2012) stated that the practice of contemplation in classroom learning developed critical thinking skills, focus and concentration, insight, compassion, connection, creativity, self-regulation, moral and ethical understanding and mental development. The practice of contemplation 
integrated in learning has been shown to improve learning outcomes (Zeidan et al., 2010), spirituality (Davidson et al., 2012), developed emotional management (Zajonc, 2013), and developed self- regulation (Tang et al., 2014).

Although the practice of contemplation in class only help students to develop their ability to concentrate, social care, manage emotions and stress, improve spirituality, and improve learning outcomes, research has shown that the practice of contemplation in the curriculum has not been conceptually tight (Ergas, 2017). Many of these contemplation practices have not considered the complexity of learners and are generally limited to the goals of managing stress, emotions and attention of students (Davidson et al., 2012; Zajonc, 2013; Shapiro et al., 2015; Bostic et al., 2015), and separating religion from knowledge (Barbezat \& Bush, 2014). Contemplation is a separate thing from learning or subject matter. In other words, the bifurcation between "serving science" or "knowledge"and"self" still occurs in learning process.

The most common contemplation techniques were mindfullness and yoga with respiratory as objects of contemplation (ACMHE, 2017). Only very few studies have specifically develop the practice of contemplation by making subject matter as the object of contemplation, such as (Song and Muschert, 2014; Delfita and Andrizal, 2016; Khayankij, 2017). These three articles are only limited to showing specific steps in the practice of contemplation applied in their classes. It is not report whether the application of the practice of contemplation in this learning meets the criteria of a learning model or not.

The scarcity of information about the practice of contemplation that makes subject matter as the object of contemplation and fulfillment of the criteria of a learning model that integrates the practice of contemplation is unfortunate. So, this information can be a reference to assess whether or not the goal of learning is achieved. This purpose of this research was to develop a contemplationbased learning model for perspective teachers of Biology. This study aims to develop contemplation-based learning models in the General Biology course and examining the feasibility of the contemplation-based learning model developed.

\section{METHOD}

Research and Development (R\&D) with five phases of Analysis, Design, Development, Implementation and Evaluation or ADDIE was conducted (Molenda, 2003). Analysis is the stage of needs analysis and identification of problems found in the Biology Eucation Department, Faculty of Tarbiyah and Teacher Training, State Islamic Institute (IAIN) Batusangkar. The stage of needs analysis by analyzing the characteristics of the Biology curriculum in the General Biology course and analyzing the characteristics of students. Problem identification done to find out the problems that exist in the learning of General Biology. Identify this problem through interview activities with General Biology lecturers and documentation studies on General Biology Semester Learning Plan (Rancangan Pembelajaran Semester).

The design stage is the stage of designing a contemplation-based learning model that conceptually addresses the analysis stage. This stage produced a prototype or a draft book of contemplationbased learning models. Meanwhile, the stage of assessment of the prototype and revision of prototype were based on expert input. Product quality is determined by formative evaluation by experts review (Nieveen \& Folmer, 2013). The results should show the valid prototype. If not so, the prototype should be revised and formative evaluation is redone (Plomp, 2010). Prototype were evaluated formatively based on paper based on expert judgment (three experts of instructional technology education, Islamic education and language).

The implementation phase is the stage of implementing a learning model that is valid 
in the classroom. The implementation of the model is carried out in the General Biology class B, 2017-2018 academic years and three times courses. This stage obtained data on the activities of lecturers and student. The evaluation phase is the assessment phase of the model that has been implemented in the class using summative evaluation which aims to find out the practicality of contemplationbased biology learning models. This model assessment was carried out by filling out questionnaires by three observers (biology lecturers). The score of expert judgment and observation on implementation contemplation based learning model is calculate with descriptive statistic (mean and standard deviation).

\section{RESULT AND DISCUSSION}

Developing a contemplation-based learning model reflected in some aspects: process of design, construction of model, and feasibility based on validity and practicality.

\section{Process of Design}

At process of design, a contemplationbased learning model develop based on good practical education and reality. The related condition was identified as analysis stage, such as the problems in biology curriculum and characteristic of students. Developing a contemplation based biology learning model is also constructed based on educational design research or/and developmental research (Richey, Klein, \& Nelson, 2002). This result showed that product met the fundamental aspect of the study. This product also met another qualification that was designed through identification process. The product was designed through cyclical process in activities of design, assesment and revision. So, it is the logical consistency and comformity between expectation and reality (Nieveen, 2007). Formative evaluation (Tessmer, 1993) was done at once and reflected in systematic documentation. A contemplation-based learning model not only done to integrate "serving scienece" and "self-knowledge" but also done in order to integrate science and religion in order to respond the vision of islamic universities in indonesia. So, the process of design a contemplation-based learning model based on good practical education and reality.

\section{Construction of Model}

The contemplation-based learning model was constructed by specific program. They were contemplation characteristic, Islamic values based on Al Asma' Al Husna, subject matter as object of contemplation, has five components of the learning model (syntax, principle of reaction, the effects of intructional and nuturant effect, and supporting system), integrated "knowledge" and " self" and integrated science and religion. The contemplation characteristics were connected directly with the object of contemplation through concentration meditation and have full awareness through mindfulness meditation (Zajonc, 2009; Center for Contemplative Mind in Society, 2016). This result showed that product met the characteristic contemplation. These characteristics are found in the fourth stage of the learning syntax.

Islamic values based on Al Asma' $A l$ Husna contained in the material are used as the first stage of the learning model to facilitate the stages of contemplation. The Islamic values are compassion (Ar-Rahman wa Ar-Rahim), nurturing (As-Salam, AlHafizh, Al Muqit), the value of justice (Al'Adl, Al-Muqsith), thoroughness (Al-Lathif), self reflection (Al-Hasib, Al-Muhshi), commitment (Al-Barr), beneficiaries (AnNafi') and others. These value was chosen one of them to be instilled in the stage of cultivating value and contemplation (Table 1). Cultivating good values purposed to bring mental attitude to do kindness (Zajonc, 2009). Salleh, (2009) stated that directly incorporating Islamic values and making emotions of students touched will form a selfknowledge skill that can finally realize that value in life. If the values are cultivated, students will take care of each other, take care 
of nature, have empathy and so on, so that the moral crisis can be dammed.

The component learning model are syntax, principle of reaction, the effects of intructional and nuturant effect, and supporting system (Joyce and Weill, 1992). This result showed that the product met qualification as a learning model can be seen at Figure 1.

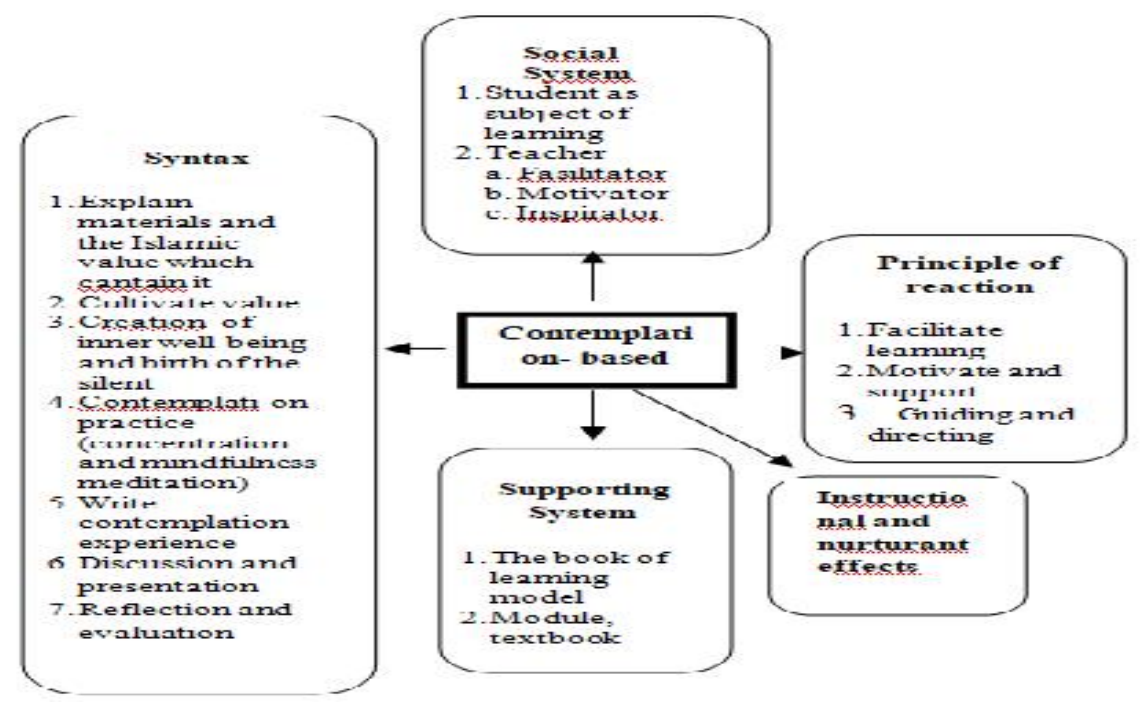

Figure 1. The Costruction of Contemplation-based Learning Model.

\section{Syntax of Contemplation-based Learning Model}

Syntax is stages of activities carried out by lecturers and students, which include the preliminary, core and closing activities. The syntax of contemplation-based learning models consists of seven stages: explain the learning subject matter and values which contain it, cultivation of values, creation of inner well-being and birth of the silent self, contemplation practice, write the contemplation experiences, small discussion and presentation, reflection and evaluation as on Table 1.

Table 1. Syntax of Contemplation-based Biology Learning Model.

\begin{tabular}{|c|c|c|}
\hline Stage of learning & Activities & Descriptive of Activities \\
\hline Prelimi-nary activities & $\begin{array}{l}\text { Setting up conditions for learning } \\
\text { (7-10 minutes). }\end{array}$ & $\begin{array}{l}\text { - Say Assalamu'alaikum and pray } \\
\text { - Giving motivation } \\
\text { - Explain learning objective } \\
\text { - Explain the learning model that will be used. }\end{array}$ \\
\hline Core activities & $\begin{array}{l}\text { Explain the learning subject } \\
\text { matter and values Which contain } \\
\text { it ( } 30-40 \text { minutes) } \\
\text { The first stage }\end{array}$ & $\begin{array}{l}\text { - Teach the students about human nature based } \\
\text { on al Quran } \\
\text { - Connect human nature with the learning } \\
\text { subject matter. } \\
\text { - Explain the learning subject matter and values } \\
\text { which contain it and small discussion about it. } \\
\text { - Ask the students to explore the others value. } \\
\text { - Select and assign a value to cultivate } \\
\text { - Ask the students about the value that has been } \\
\text { set beforehand and immediately answer them. } \\
\text { For example, "Have I become human being } \\
\text { that....discipline or regularly life (according to } \\
\text { the set value). } \\
\text { - Associate students answer with Allah's } \\
\text { purpose to create order in each of His creation } \\
\text { - Bring humility and self awareness in the } \\
\text { presence of Allah SWT. }\end{array}$ \\
\hline
\end{tabular}




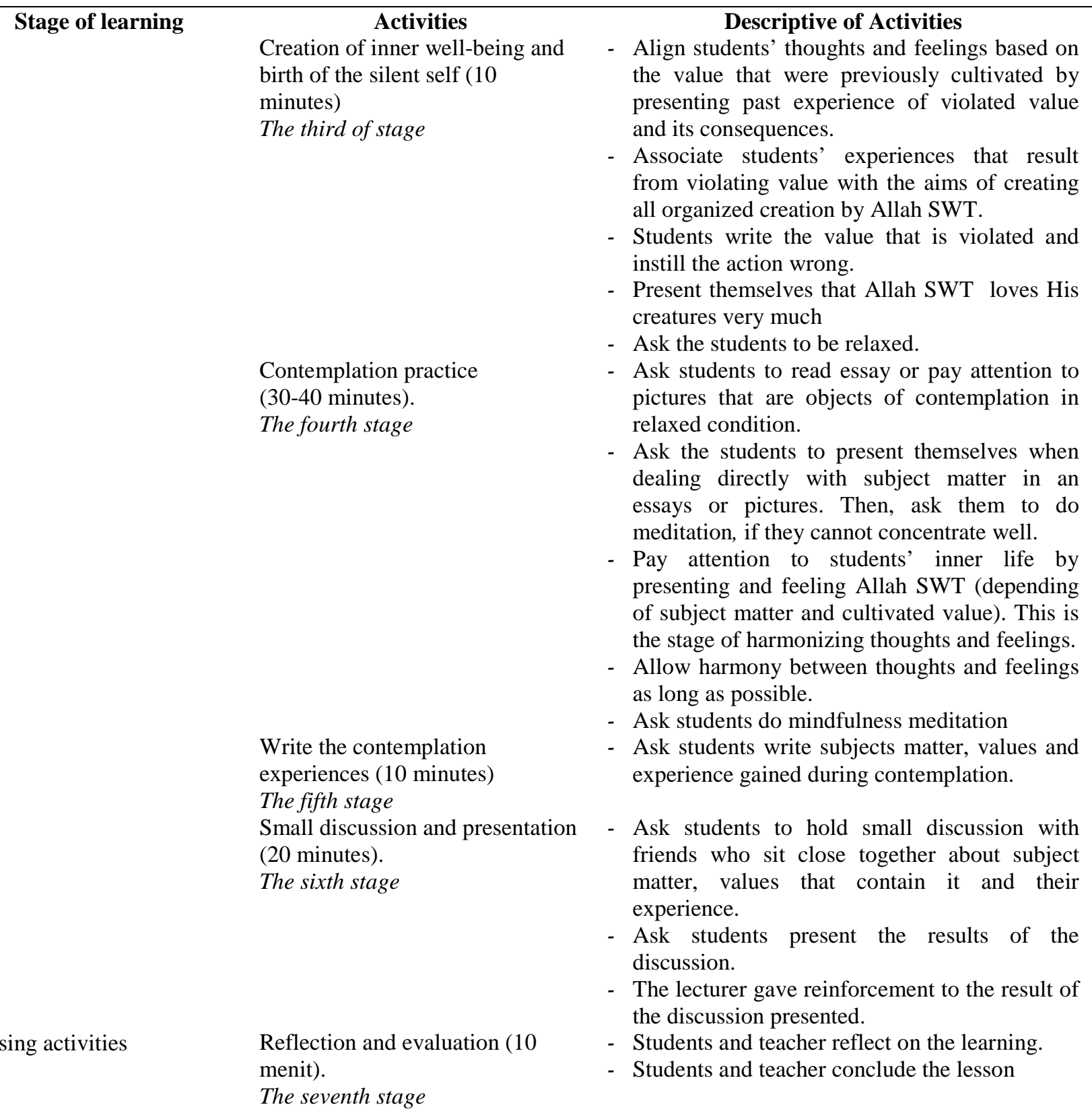

In the preliminary stage, students faced the phenomenon of irregularities in the lives of students with the order of creation by Allah SWT (depending on material) to motivate and explore their initial knowledge. Cook \& Ausubel, (1970) stated that educators must find ways to connect new learning material with the knowledge of previous students and prepare their students to receive new information. Comparing contradictory things is seen as a solution to attract and motivate students (Ambrose \& Lovett, 2014; Schneider, Nebel, Beege, \& Rey, 2018). If students are motivated, they will pay attention to the learning given, related it to their previous knowledge and ask questions (Schunk, 2012).

The core phase begins with explained the nature of the human being based on al Quran and then connecting human nature with the learning subject matter and the values that contain it.The lecturer explained the subject matter and values contained in it based on Al Asma' $A l$ Husna (the first stage). At this stage, students gain exposure to the subject matter and values contained in it. 
The second syntax of this learning is cultivating value. This stage aims to evaluate themselves (self-reflection) and instill values to foster self-regulation so that they can change their bad qualities both at home and on campus. Hayward and Colman, (2010) state that values and principles arecultivated in someone when they can be interconnect the realities of nature and their full benefits. Salleh, (2009) states that directly incorporating Islamic values and making emotions of students touched will form a selfknowledge skill that can finally realize that value in life. If the values are cultivated, then students will take care of each other; take care of nature, empathy and so on, so that the moral crisis can be dammed. Selfregulation greatly helps students to maintain self-efficacy for learning, learning values, beliefs to achieve goals and maintain emotional stability (Schunk, 2012). This phase also aims to create a positive learning environment that makes it easier for students to enter the next stage of learning, which facilitates the emergence of humility and the practice of contemplation. Humility and full surrender to the Creator are the foundation of the moral foundation for entering the stage of meditation (Zajonc, 2009).

The third syntax of this learning model is the creation of inner calm. At this stage students re-relax their bodies by presenting violated values and their consequences (according to the material and values previously invested). The violated value is written and implanted that the violated value is wrong. For example, in material structure and function of animals, when paying attention to figures of animal anatomical structures, students feel the love of Allah SWT through its design and structure is very fitting and amazing according to its function. This will make students realize that Allah is the Most Nurturing, so that humility is formed and gives birth to inner peace. This sense of comfort and inner calm can developed students' confidence and ability to convey ideas and opinions (Liu \& Lin, 2012). After they get a sense of comfort, followed by the phase of practice of contemplation which consists of concentration and mindfulness meditation.

The fourth syntax is contemplation practice. The object of contemplation in the form of essay or figure of General Biology material that has been designed in accordance with the indicators of learning. In concentration meditation students are asked to read essays or pay attention to the figure in 3-5 minutes detail in a relaxed state and without thinking about anything. If their attention is disturbed, repeat reading the essay or paying attention to the figure. When this concentration meditation takes place, the lecturer directs students to turn their attention to their inner lives (harmonizing their thoughts and feelings) by presenting and feeling the presence of Allah SWT through the subject matter that they contemplate. This will describe the harmony of thoughts and feelings. Students are asked to maintain the conditions of harmony of their thoughts and feelings as long as possible (mindfullness meditation) and allow whatever arises as long as they harmonize their thoughts and feelings. At the time of concentration meditation, the processing of course material information occurs in depth and is more reflective so that the information is easily connected to one another and will enter into long-term memory (Kapur et al., 1994). The values contained in the subject matterl will enter and touch the emotions of students (Salleh, 2009).

At biologically, meditation changed of parts of the brain responsible for processing emotions, and has a powerful effect on the amygdala, the brain's trigger for fear, stress, and anger (Lazar, 2013). Holzel et al., (2011) reported that increases in gray matter concentration within the left hippocampus, increased in the posterior cingulated cortex, the temporo-parietal 
junction, and the cerebellum. The results suggest that it is associated with changes in gray matter concentration in brain regions involve in learning and memory processes, emotion regulation, self-referential processing, and perspective taking. Lazar, (2013) also reported that the temporalparietal junction involved empathy and love and thickening of the brain stem area (pons), the place of production of the neorotransmitter regulator. In the amygdala, an important place of defense for regulating anxiety, fear and stress becomes reduction in thickening (Lazar, 2013; Desbordes et al., 2012). Research showed that meditation carried out for eight weeks can evoke a brain response. The connectivity between the prefrontal cortex, hippocampus and amygdala shows a neuronal mechanism of action about how this meditation training induces emotional and behavioral changes (Holzel et al., 2011; Gotink et al., 2016). Studies using neuroimaging techniques have shown that meditation increases activation and connectivity in areas of the brain related to self-regulation (Tang, Posner, and Rothbart, 2014). This is very possible because the key characteristic of the practice of contemplation is that they represent a form of mental training that can cause changes in plasticity in the brain (Lutz, et al., 2008). The heart of the practice is repetition and practice to cultivate more positive habits of mind. When positive thoughts are trained, the part of the brain responsible for self regulation will be active (Beauregard, Lévesque, \& Bourgouin, 2001).

Barbezat \& Bush, 2014) stated that the practice of contemplation forms an independent thinker person, develops problem solving skills, provides opportunities for students to connect directly with the material and values and interpret the values that exist in the material so that it will be easier for them to apply it to their daily lives. The practice of contemplation build students' life skills such as building concentration and attention (Jha, Krompinger, \& Baime, 2007), which will have an impact on cognitive (Zeidan et al., 2010; Campagne, 2013; Tang et al., 2014). Song and Muschert, (2014) state that the thought process will be deep and holistic. The practice of contemplation builds the ability of students to manage emotions (Davidson et al., 2012; Zajonc, 2013), reduces anxiety (Campagne, 2013) fosters selfknowledge (Barbezat and Pingree, 2012) increases self regulation (Tang et al., 2014), fostering compassion, and increasing spirituality (Davidson et al., 2012; Zajonc, 2013). Khayankij, (2017) reports that contemplation can develop student awareness. The practice of contemplation is very practical in overcoming the problem of contemporary education and is a simple method (Hart, 2004). The students not only have "knowledge" or "service science", but also have self-knowledge.Self-knowledge" is key to the cultivation of a life of meaning and virtue. It unfolds within a pedagogical space in which meaning becomes personal meaning within a social sphere and moral action becomes a deliberate choice (Ergas, 2017). In other words, this contemplationbased biology learning model can eliminate the gap in "serving science" and "knowledge of self". So, that the goal of education is to create a well human being and "moral crisis" is overcome.

The practice of contemplation applied in this learning model has the same characteristics as the practice of contemplation that has been applied in Buddhist schools and universities in America and Europe. The difference in the practice of contemplation in this learning model is the object of contemplation in the form of subject matter in the General Biology course and the values that are cultivated derived from the value of Al Asma' Al-Husna. The technique is to read essays and pay attention to picture related to subject 
matter. The objects of contemplation in Buddhist schools and universities in America and Europe were generally breathing(Center for Contemplative Mind in Society, 2013), singing, painting and dancing (Khayankij, 2017), and self (Song and Muschert, 2014).The contemplation practice in Buddhist schools and universities in America and Europe separated religion and knowledge (Barbezat \& Bush, 2014).

The fifth syntax of this model is to write the contemplation experiences. Writing the students experience can summarize and reflect on the lesson. Writing the experience is not a simple process, it affects the development of skills such as thinking and expressing. Writing experience helped student developed communication skill and remember their lesson (Günel, Uzoğlu and Büyükkasap, 2009), developed student analytical skills, their skills of remembering, commenting, eliminating misconceptions, reinforcing the subject and making reasonable explanation (Seven, Pinar Koksal, \& Kocak, 2017; Satriani, Emilia \& Gunawan, 2012). So, writing in this learning model will significantly improve student learning outcomes.

The sixth syntax is a small discussion and presentation. A small discussion aims to share information related to the things obtained during contemplation. This stage is continued with the presentation. This stage was importent aspect of learning, such as promotes critical thinking by forcing student to apply what they have learned in the classroom to information that they gathered (Girard, Pinar, \& Trapp, 2011). Presentations allowed students to communicate their understanding of concepts to their peers and foster an environment for the discussion of those concepts (Thor et al., 2017). In addition, interactions ofstundent stimulated and encouraged cognitive growth (Schunk, 2012).
The seventh syntax is a reflection and evaluation. The activity at this stage aims to determine the extent to which students master the indicators given and know what obstacles are in learning to be used as materials for improving learning. This phase is an important phase for lecturers and students. It is help lecturer to understand better how students think and how support them in learning (Ash, Clayton, \& Atkinson, 2005). Lecturers can find out the obstacles that occur and the degree to which students master the concepts that are the goals of learning (Cooperstein, 2004).

\section{Social System}

The social system describes the role of lecturers and students during learning. In this contemplation-based learning model students acted as subjects of learning, had an active role in thinking, building ideas, looking for values contained in the subject matter, cultivating values, contemplating, asking questions, discussing and communicating and determining attitudes. Lecturers acted as facilitators in planning learning, creating a conducive learning environment, increasing intellectuality and student spirituality. Lecturers also acted as motivators in cultivating values, giving awards. In addition, lecturers also acted as inspirators who play a role in encouraging and creating new ideas. The point is that in the social system the learning model gave rise to social aspects in the classroom and a pleasant learning atmosphere so that it invites students to be open, discuss and convey ideas that ultimately have a positive impact on learning outcomes. In the social system of this model, an environment of the classroom is very cooperative on the basis of the mutual and high feeling of emotional activities. 


\section{Principle of Reaction}

The reaction principle shows the activities of lecturers and students during learning. The activities of lecturers in contemplation-based learning models include conveying subject matter and imitating the values contained in it, exemplifying ways to contemplate, asking students to read essays or pay attention to images. Lecturers can also participate in contemplating and asking questions regarding the material and the results of contemplation. While student activities include listening to the explanation of the subject matterl and values contained in the material, showing the values that exist in the material based on Al Asma' Al-Husna, choosing and setting the values to be implanted, reading essays or paying attention to figures, contemplating, writing down the results of contemplation, discussing, delivering results contemplation, asking questions and answering questions at the end of learning. The point is how lecturers choose what reactions are effective for students.

\section{Supporting System}

The support system for the contemplation-based learning model was a model book, module and textbook. Modules are arranged as a reference for students that contain material equipped with values and guidance on contemplation-based learning models. Another support system is the expertise of lecturers.

\section{Instructional and Nurturant Effects}

The instructional effects of this model is to develop knowledge and knowledge of self, to construct knowledge and consideration of values, practice concentration, balance thoughts and feelings, control self and enhance spirituality. This instructional impact will make the achievement of subject competencies and make values as guidelines for behavior. While, the nurturant effects is to develop communication skill, self-reflection, increase interest, motivation, responsibility, caring and self-confidence.

\section{Feasibility of Contemplation-based Learning Model}

Feasibility of this model conduct based validity and practicality. The feasibility of contemplation-based learning model has a value of $3.29 \pm 0.13$, with very valid categories (Table 2) and $3.47 \pm 0.09$, with very practical categories (Table 3 ). That is, contemplation-based learning model met the criteria of the learning modeland are feasible to use. As stated by Nieveen, (1999) that a learning model is said to be good if it is valid, practical and effective. Nineveh further stated that the validity aspect of a model is associated with two things: strong theoretical rationality and internal consistency of the components developed. The contemplation-based learning has fulfilled this aspect of validity.

Table 2. The Validity Score of Contemplationbased Learning Models

\begin{tabular}{clc}
\hline No & Aspects of assessment & Average \\
\hline 1 & The supporting theory & $3.25 \pm 0.43$ \\
2 & Syntax & $3.43 \pm 0.06$ \\
3 & Social system & $3.33 \pm 0.16$ \\
4 & Priciple of reaction & $3.06 \pm 0.10$ \\
5 & Instructional and & $3.28 \pm 0.13$ \\
& nurturant effects & \\
6 & The supporting system & $3.39 \pm 0.19$ \\
\multicolumn{2}{c}{ Average } & $3.29 \pm 0.13$ \\
\hline
\end{tabular}

Description: If the average $\geq 3.20$ category is very valid, 2.40 <average $\leq$ 3.20 categories are valid, 1.60 <average $\leq$ 2.40 the categories is quite valid, 0.80 <average $\leq 1.60$ categories are less valid, If the average $\leq 0.80$ category is invalid.

Atthe practical aspect, contemplation-based learning model can be easily used by lecturer. Plomp, (2010) 
and Nieveen, (1999), a model is said to be practical if it can be used easily and practically by users.

Table 3. The Practicality Score of Contemplationbased Learning Models.

\begin{tabular}{lll}
\hline No & Aspects of assessment & Average \\
\hline 1 & Sintax & \\
& Preliminary activities & $3.44 \pm 0.08$ \\
& Core activities & $3.49 \pm 0.07$ \\
& Closing activities & $3.56 \pm 0.1$ \\
& Average & $3.50 \pm 0.02$ \\
2 & Social system & $3.57 \pm 0.11$ \\
3 & Priciple of reaction & $3.22 \pm 0.33$ \\
& Overall average & $3.47 \pm 0.09$ \\
\hline
\end{tabular}

Description: If the average $\geq 3.20$ category is very practical, 2.40 <average $\leq$ 3.20 categories are practical, 1.60 <average $\leq 2.40$ the categories is quite practical, 0.80 <average $\leq 1.60$ categories are less practical, If the average $\leq 0.80$ category is impractical.

However, this learning model requires special interventions from Islamic universities and stakeholders so that they can be used as a basis or reference to include and apply this learning model in the curriculum. Because the implementation of this contemplationbased learning model integrates to general science and religious sciences in the level of subject matter so that the vision and mission of Islamic universities and stakeholders are achieved. Islamic values instilled when learning and contemplation support the formation of graduates with Islamic characteristics, better human being, know about themselves, care for others and the environment. The "moral crisis" which has been accused of higher education as a result of separating "serving science" and "self knowledge" is resolved by applying this learning model in the curriculum.

\section{CONCLUSION AND RECOMMENDATION}

The contemplation-based learning model that developed for biology prospective teachers are feasible based on the aspect of validity and practicality. This model will stop the bifurcation "serving science" and "self-knowledge" and is a model to integrate science and religionat Islamic Education. However, effects of implementation of contemplation-based learning model on the student learning outcomes, spiritual and socio-emotional has not been studied.

\section{REFERENCES}

ACMHE. (2017). The Association for Contemplative Mind in Higher Education (ACMHE) from Vision and Mission Statement.

Ambrose, S. A., \& Lovett, M. C. (2014). Prior knowledge is more than content: Skills and beliefs also impact learning. In Applying science of learning in education: Infusing psychological science into the curriculum (pp. 7-19).

Ash, S. L., Clayton, P. H., \& Atkinson. (2005). Integrating Reflection and Assessment to Capture and Improve Student Learning. Michigan Journal of Community Service Learning, 11(2005), 49-60. https://doi.org/10.1080/15504263.201 6.1174010

Barbezat, D, Pingree, A. (2012). Contemplative pedagogy: The special role of teaching and learning centers. In C. L. Groccia, J. E., \& Cruz (Ed.), To improve the academy: Resources for faculty, instructional, and organizational development (pp. 177191). San Fransisco: Jossey-Bass.

Barbezat, D.P., \& Bush, M. (2014). Contemplative practices in higher education: Powerful methods to transform teaching and learning. San Francisco, CA: Jossey-Bass.

Beauregard, M., Lévesque, J., \& Bourgouin, P. (2001). Neural 
Correlates of Conscious SelfRegulation of Emotion. The Journal of Neuroscience, 21(18), RC165$\mathrm{RC} 165$.

https://doi.org/10.1523/JNEUROSCI. 21-18-j0001.2001

Bostic, J. Q., Nevarez, M. D., Potter, M. P., Prince, J. B., Benningfield, M. M., \& Aguirre, B. A. (2015). Being Present at School. Implementing Mindfulness in Schools. Child and Adolescent Psychiatric Clinics of North America, 24(2), 245-259. https://doi.org/10.1016/j.chc.2014.11. 010

Campagne, D. M. (2013). Theory and physiology of meditation. Cuadernos de Medicina Psicosomática $Y$ Psiquiatria de Enlace, (105), 6.

Center for Contemplative Mind in Society. (2013). Abaut the tree contemplative practice. Retrieved January 12, 2016, from www.contemplativemind.org

Colby, A., Ehrlich, T., \& Sullivan, W. M. (2011). Rethinking undergraduate business education. The carnegie foundation for the advancement of teaching.

https://doi.org/10.1017/CBO9781107 415324.004

Cook, H., \& Ausubel, D. P. (1970). Educational Psychology: A Cognitive View. The American Journal of Psychology, 83(2), 303. https://doi.org/10.2307/1421346

Davidson, R. J., Dunne, J., Eccles, J. S., Engle, A., Greenberg, M., Jennings, P., ... Vago, D. (2012). Contemplative Practices and Mental Training: Prospects for American Education. Child Development Perspectives, 6(2), 146-153. https://doi.org/10.1111/j.17508606.2012.00240.x

Delfita, R, Andrizal, A. (2016).
Pendekatan pedagogi kontemplatif dalam pembelajaran sains pada perguruan tinggi Islam dalam rangka integrasi sains dan agama. In The 16th Annual International Conference on Islamic Studies (AICIS) 2016 (pp. 18).

Desbordes, G., Negi, L. T., Pace, T. W. W., Wallace, B. A., Raison, C. L., \& Schwartz, E. L. (2012). Effects of mindful-attention and compassion meditation training on amygdala response to emotional stimuli in an ordinary, non-meditative state. Frontiers in Human Neuroscience, 6(November), 1-15. https://doi.org/10.3389/fnhum.2012.0 0292

Ergas, O. (2017). Reclaiming ethics through "self": A conceptual model of teaching practice. Teaching and Teacher Education, 68, 252-261. https://doi.org/10.1016/j.tate.2017.09. 013

Gilead, T. (2012). Education and the Logic of Economic Progress. Journal of Philosophy of Education, 46(1), 113131. https://doi.org/10.1111/j.14679752.2011.00838.x

Girard, T., Pinar, M., \& Trapp, P. (2011). An Exploratory Study of Class Presentations and Peer Evaluations: Do students perceive the benefits? Academy of Educational Leadership Journal, 15(1), 77-94.

Gotink, R. A., Meijboom, R., Vernooij, M. W., Smits, M., \& Hunink, M. G. M. (2016). 8-week Mindfulness Based Stress Reduction induces brain changes similar to traditional longterm meditation practice - A systematic review. Brain and Cognition, 108, 32-41. https://doi.org/10.1016/j.bandc.2016.0 7.001

Günel, M, Uzoğlu, M , Büyükkasap, E. 


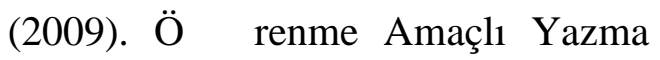
Aktivitelerinin Kullanımının lkö $\breve{g}$ retim Seviyesinde Kuvvet Konusunu Ö ğ renmeye Etkisi. G $\ddot{U}$, Gazi Eğitim Fakültesi Dergisi, 29(1), 379-399.

Hart, T. (2004). Opening the Contemplative Mind in the Classroom. Journal of Transformative Education, 2(1), 28-46. https://doi.org/10.1177/15413446032 59311

Hayward K, Colman, K. (2010). Educating for Gross National Happiness. In Educating for Gross National Happiness (p. 44). Bhutan.

Holzel,BK, Carmody,J, Vangel,M, Congleton,C, Yerramsetti,SM, Gard, T. and L. S. (2011). Mindfulness practice leads to increases in regional brain gray matter density. Psychiatry Res, 191(1), 36-43. https://doi.org/10.1016/j.pscychresns. 2010.08.006.Mindfulness

Jha, A. P., Krompinger, J., \& Baime, M. J. (2007). Mindfulness training modifies subsystems of attention. Cognitive, Affective \& Behavioral Neuroscience, $7(2)$, 109-119. https://doi.org/10.3758/CABN.7.2.10 9

Joyce, B., Weill, M. (1992). Models of teaching (6th ed.). Boston: Allyn \& Bacon.

Kandiko, Camille B. (2010). Neoliberalism in Higher Education: A Comparative Approach. International Journal of Arts and Sciences, 3(14), 153-175.

Kapur, S., Craik, F. I., Tulving, E., Wilson, A. A., Houle, S., \& Brown, G. M. (1994). Neuroanatomical correlates of encoding in episodic memory: levels of processing effect [see comments]. Proceedings of the National Academy of Sciences U.S.A., 91(6), 2008-2011. https://doi.org/10.4324/97813154404 46

Khayankij, S. (2017). Using the contemplative teaching method to enhance the awareness of the aesthetic experience of second-year students majoring in early childhood. Kasetsart Journal of Social Sciences, $1-7$.

https://doi.org/10.1016/j.kjss.2017.09. 005

Kleinman, D. L., Feinstein, N. W., \&Downey, G. (2013). Beyond Commercialization: Science, Higher Education and the Culture of Neoliberalism. Science and Education, 22(10), 2385-2401. https://doi.org/10.1007/s11191-0129482-4

Lazar, S. (2013). Meditation and neuroscience. The Healing Power of Meditation: Leading Experts on Buddhism, Psychology, and Medicine Explore the Health Benefits of Contemplative Practice.

Lelwica, M. M. (2009). Embodying learning: Post-cartesian pedagogy and the academic study of religion. Teaching Theology and Religion, 12(2), 123-136. https://doi.org/10.1111/j.14679647.2009.00507.x

Lewis, H. . (2006). Excellence without a soul: Does liberal education have a future? New York: Public Affairs.

Liu, E. Z., \& Lin, C. (2012). CreativitySupporting Learning Environment in Higher Education. The Turkish Online Journal of Educational Technology, 11(1), 172-181. https://doi.org/10.1128/IAI.73.1.592

Lutz,A,Brefczynski-Lewis,J.A, Johnstone,T,Davidson, R. . (2008). Regulation of the neural circuitry of emotion by compassion meditation: 
Effects of meditative expertise. PLoS ONE, 3(3), 1-10. https://doi.org/10.1371/journal.pone.0 001897

Molenda, M. (2003). In search of the elusive ADDIE model. Performance Improvement, 42(5), 34-36. https://doi.org/10.1002/pfi.493042050 8

Nieveen, N. (1999). Prototyping to Reach Product Quality. In J. (eds) Plomp, T; Nieveen, N; Gustafson, K; Branch, R.M; dan van den Akker (Ed.), Design Approaches and Tools in Education and Training. London: Kluwer Academic Publisher.

Nieveen, N. (2007). Formative Evaluation in Educational Design Research. In Tjeerd \& P. and N. Nieveen (Eds.), The seminar conducted at the East China Normal University, Shanghai (PR China) (p. 89-102.). Enschede: SLO Netherlands Institute for Curriculum Development.

Nieveen, N., \& Folmer, E. (2013). Formative evaluation in educational design research. Design Research, 153, 152-169.

Plomp, T. (2010). Educational design research: an introduction. In T. P. and N. Nieeven (Ed.), An introductional to educational design research, (p. 9). Netherland.

Richey, R. C., Klein, J. D., \& Nelson, W. A. (2002). Developmental research: studies of instructional design and development. In David Jonassen (Ed.), Handbook of research on educational communications and technology (p. 1101). Washington: Association for Educational Communications and Technology.

Ruedy, N. \&, \& Schweitzer, M. (2010). In the Moment: The Effect of Mindfulness on Ethical Decision
Making. Journal of Business Ethics (Vol. 95).

Salleh, M. (2009). Integrated Islamic Education: Need for Thematic Approaches. In Singapore Islamic Education System- SIES Seminar (pp. $1-13)$.

Satriani, I, Emilia, E., \& Gunawan, M. H. (2012). Contextual teaching and learning approach to teaching writing. Indonesian Journal of Applied Linguistics, 2(1), 10-22.

Schneider, S., Nebel, S., Beege, M., \& Rey, G. D. (2018). The autonomyenhancing effects of choice on cognitive load, motivation and learning with digital media. Learning and Instruction, 58, 161-172. https://doi.org/10.1016/j.learninstruc. 2018.06.006

Schunk, D. . (2012). Learning teories: An educational perspektive (Sixth Edit). Boston: Pearson Education, Inc.

Seven, S., Pinar Koksal, A., \& Kocak, G. (2017). The Effect of Carrying out Writing to Learn Activities on Academic Success of Fifth Grade Students in Secondary School on the Subject of "Force and Motion." Universal Journal of Educational Research, 5(5), 744-749. https://doi.org/10.13189/ujer.2017.05 0506

Shapiro, S. L., Lyons, K. E., Miller, R. C., Butler, B., Vieten, C., \& Zelazo, P. D. (2015). Contemplation in the Classroom: a New Direction for Improving Childhood Education. Educ Psychol Rev, 27(March), 1-30. https://doi.org/10.1007/s10648-0149265-3

Simmer-Brown, J. (2009). "The question is the answer"- naropa university's contemplative pedagogy. Religion and Education, 36(2), 88-101. 
https://doi.org/10.1080/15507394.200 9.10012445

Song, KY, Muschert, G. (2014). Opening the Contemplative Mind in the Sociology Classroom. Humanity \& Society, 38(3), 314-338. https://doi.org/10.1177/01605976145 37794

Tang,Yi-Yuan, Posner,MI and Rothbart, M. (2014). Meditation improves selfregulation over the life span. Ann $N Y$ Acad Sci, 1307, 104-111. https://doi.org/10.1016/j.neuroimage. 2013.08.045.The

Thor, D., Xiao, N., Zheng, M., Ma, R., \& Yu, X. X. (2017). An interactive online approach to small-group student presentations and discussions. Advances in Physiology Education, 41(4), 498-504. https://doi.org/10.1152/advan.00019.2 017

Walsh, R., \& Shapiro, S. L. (2006). The meeting of meditative disciplines and western psychology: A mutually enriching dialogue. American Psychologist, 61(3), 227-239. https://doi.org/10.1037/0003066X.61.3.227

Zajonc. A. (2009). Meditation as Contemplative Inquiry: When Knowing Becomes Love. Intelligence. Massachusetts 01230: Lindisfarne Books.

Zajonc, A. (2013). Contemplative Pedagogy: A Quiet Revolution in Higher Education. New Directions for Teaching and Learning, (119), 35-41. https://doi.org/10.1002/tl

Zeidan, F., Johnson, S. K., Diamond, B. J., David, Z., \& Goolkasian, P. (2010). Mindfulness meditation improves cognition: Evidence of brief mental training. Consciousness and Cognition, 19(2), 597-605. https://doi.org/10.1016/j.concog.2010. 03.014 